CORRECTION OPEN

\title{
Correction: DCLK1 isoforms and aberrant Notch signaling in the regulation of human and murine colitis
}

Badal C. Roy, Ishfaq Ahmed, Jason Stubbs, Jun Zhang (D), Thomas Attard, Seth Septer, Danny Welch, Shrikant Anant (D), Venkatesh Sampath and Shahid Umar

(c) The Author(s) 2021

Cell Death Discovery (2021)7:200 ; https://doi.org/10.1038/s41420-021-00586-x

Correction to: Cell Death Discovery https://doi.org/10.1038/s41420021-00526-9, published online 17 June 2021

The original version of this article unfortunately contained a mistake in Figure 3. Figure $3 \mathrm{~F}$ was in addition to Figure $5 \mathrm{C}$. Figure $5 \mathrm{C}$ clearly defines the findings explained in the text under the heading " $C R$ infection increases the expression of DCLK1, a tuft cell marker, in the colons of immune-incompetent mice". Thus, Figure 3 was revised. The authors apologize for the mistake. The original article has been corrected. 
A.
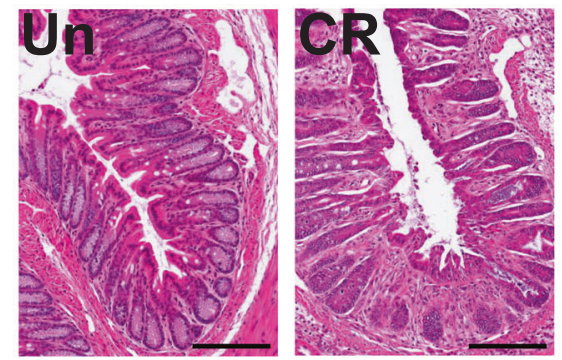

C.

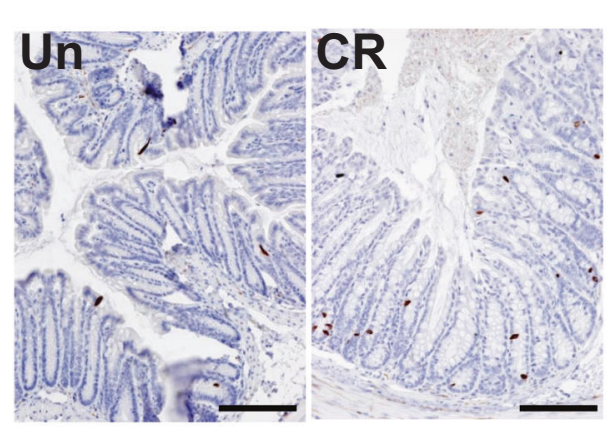

E.
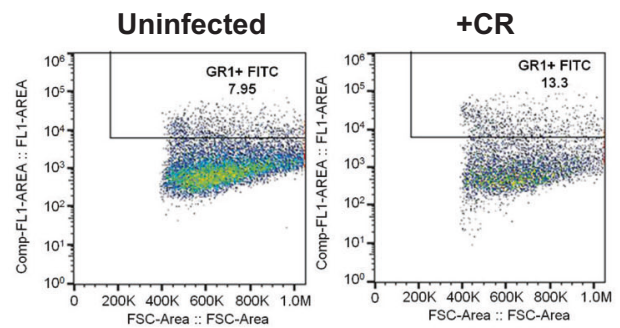

FSC-Area $=$ FSC-Area
B.
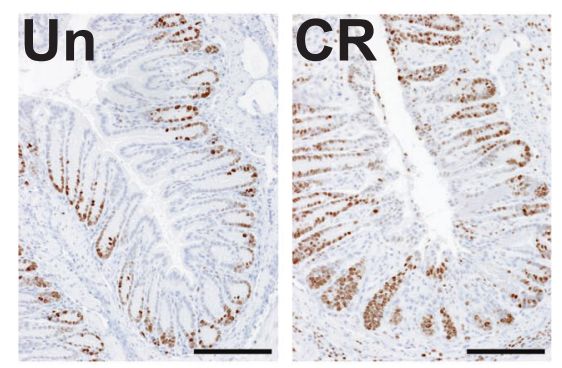

D.
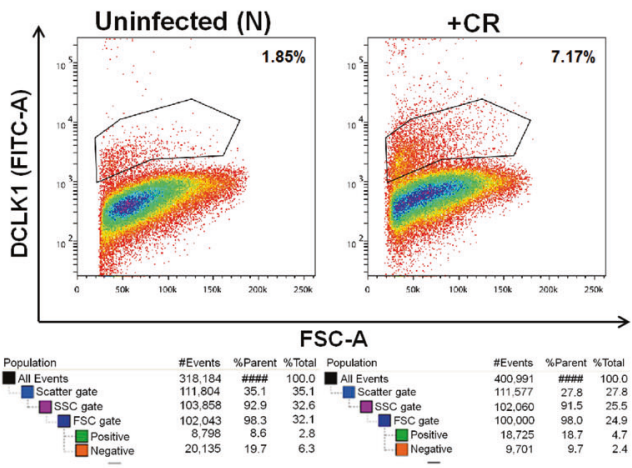

Open Access This article is licensed under a Creative Commons Attribution 4.0 International License, which permits use, sharing, adaptation, distribution and reproduction in any medium or format, as long as you give appropriate credit to the original author(s) and the source, provide a link to the Creative Commons license, and indicate if changes were made. The images or other third party material in this article are included in the article's Creative Commons license, unless indicated otherwise in a credit line to the material. If material is not included in the article's Creative Commons license and your intended use is not permitted by statutory regulation or exceeds the permitted use, you will need to obtain permission directly from the copyright holder. To view a copy of this license, visit http://creativecommons. org/licenses/by/4.0/.

(c) The Author(s) 2021 